\title{
Increase in rice grain arsenic for regions of Bangladesh irrigating paddies with elevated arsenic in groundwaters
}

Williams PN, Islam MR, Adomako EE, Raab A, Hossain SA, Zhu YG, Feldmann J \& Meharg $\mathbf{A A}^{1^{*}}$

Supporting Information

Pages $=19$

Figures $=\mathbf{3}$

Tables $=5$ 


\section{Contents}

$\begin{array}{lll}\text { Part A Chemical Analysis } & \text { S3-S6 }\end{array}$

Fig S1 Geographical distribution of arsenic levels $\quad$ S7 in Bangladesh rice

Fig S2 District map of Bangladesh S8

Part B Summary of the arsenic levels and speciation S9-S11 in Bangladesh vegetables, pulses and spices.

Part C Dietary exposure of arsenic from S11-S12 Bangladesh vegetables, pulses and spices

Table S1 Range and average of arsenic concentrations $\quad$ S13 expressed on a dry weight basis for vegetables, pulses and spices

Table S2 Arsenic speciation of $\quad$ S14

Bangladesh vegetables, pulses and spices

Table S3 Speciation Analysis of Rice Flour Reference $\quad$ S15 Material (NIST CRM 1568a)

Table S4 Analysis of variance S16

Fig S3 Regression of mean groundwater arsenic $\quad$ S17 level against district As rice grain levels

Table S5 Results of the regression of district mean $\quad$ S18 groundwater As level against the mean district As rice grain levels, for Aman \& Boro season rice.

Reference 


\section{Part A:}

\section{Chemicals}

Analytical grade nitric acid $\left(\mathrm{HNO}_{3}\right)$ (70\%) and trifluoroacetic acid (TFA) $\left(\mathrm{CF}_{3} \mathrm{COOH}\right)(99 \%)$ were obtained from Fisher Scientific and Lancaster, respectively. Mono-sodium arsenate $\left(\mathrm{Na}_{2} \mathrm{HAsO}_{4}\right)$ and sodium arsenite $\left(\mathrm{NaAsO}_{2}\right)$, reagent grade were purchased from Merck.

Methylarsonic acid (MMA), was bought from Chem Service MC, West Chester and dimethylarsinic acid (DMA) from Sigma Chemicals. Indium (In) was prepared inhouse from indium chloride. The HPLC mobile phase was prepared using ammonium hydrophosphate and ammonium dihydrogen orthophosphate analytical grade from BHD Chemicals Ltd, Poole, England.

\section{Extraction Procedures}

Total Digestion: Conc. $\mathrm{HNO}_{3}$. For concentrations of total As, oven dried milled subsamples $(0.1-0.2 \mathrm{~g})$ were weighed into quartz glass digestion tubes, steeped in 2.5 $\mathrm{mL}$ of nitric acid and allowed to stand overnight at room temperature. The samples were digested at $120^{\circ} \mathrm{C}$, until clear, and then evaporated to dryness at $140^{\circ} \mathrm{C}$. The residue was resuspended in $1.2 \%$ nitric acid to a weight of $10 \mathrm{~g}$. Indium (100 $\mu \mathrm{l}$ of $100 \mu \mathrm{g} \mathrm{L}^{-1}$ ) was added as the internal standard.

Extraction: 2M TFA. Milled sub-samples (0.25 g) were weighed into quartz digestion tubes and $2 \mathrm{~mL}$ of $2 \mathrm{M}$ TFA were added. The mixture was allowed to stand 
overnight. The tubes were then placed on a heating block, at $100^{\circ} \mathrm{C}$ for 6 hours. The digest was evaporated to dryness at $160^{\circ} \mathrm{C}$ and made up to a weight of $5 \mathrm{~g}$ with distilled water

To speciate arsenic in rice, vegetables, pulses and spices, TFA was employed as an extractant. TFA hydrolyzes starch during digestion, which can result in a more successful recovery than a methanol: water extraction Abedin et al. (1). Additionally, TFA extraction does not suffer from argon chloride inference problems as found with hydrochloric acid digestions. The TFA entrant however reduces, partially, arsenate to arsenite. Therefore, this method is only suitable in determining the levels of total inorganic arsenic. Spiking experiments have shown that TFA does not convert MMA or DMA to inorganic arsenic (1).

\section{Chemical Analysis}

\section{Total Arsenic Detection}

An ICP-MS 7500c (Agilent Technologies) was used to determine total arsenic concentration. Arsenic sensitivity was monitored daily and optimised when required. The elements measured were As $(\mathrm{m} / \mathrm{z}, 75)$ and $\operatorname{In}(\mathrm{m} / \mathrm{z} 115)$. The following $\mathrm{m} / \mathrm{z} 77,78$, 82 were measured in order to identify polyatomic $\mathrm{Ar}^{40} \mathrm{Cl}^{35}$ interferences on $m / z, 75$. Corrections for interference from $\mathrm{Ar}^{40} \mathrm{Cl}^{35}$ were not found to be necessary for the samples analysed. Concentration was determined using a five-point calibration of 0,1 , 5, 10 and $20 \mu \mathrm{g}$ of As $\mathrm{L}^{-1}$. Sub-samples were randomised prior to analysis. Standards were run after every set of ten sub-samples. All samples were run in duplicate. NIST 
SRM 1568a rice flour was used as CRM. The presented data has not been corrected for recovery.

\section{Arsenic Speciation}

A HP1100 HPLC system (Agilent Technologies, Stockport, Cheshire, UK) with cooled auto-sampler and a Peltier controlled column compartment was used for all of the analyses. Chromatographic columns were obtained from Hamilton and consisted of a precolumn $(11.2 \mathrm{~mm}, 12-20 \mu \mathrm{m})$ and a PRP-X100 $10 \mu \mathrm{m}$ anion-exchange column $(150 \times 4.1 \mathrm{~mm})$. Injection volume was set at $100 \mu \mathrm{L}$ of sample and the HPLC mobile phase flow rate was maintained at $1 \mathrm{~mL} \mathrm{~min}^{-1}$. The auto-sampler was set to $4^{\circ} \mathrm{C}$ and the column to $30^{\circ} \mathrm{C}$. The mobile phase employed for anion-exchange chromatography, adapted from Heitkemper et al. (2), consisted of $6.66 \mathrm{mM}$ ammonium hydrophosphate $\left(\mathrm{NH}_{4} \mathrm{H}_{2} \mathrm{PO}_{4}\right)$ and $6.66 \mathrm{mM}$ ammonium nitrate $\left(\mathrm{NH}_{4} \mathrm{NO}_{3}\right)$, adjusted to pH 6.2 using ammonia. Prior to analysis, samples were centrifuged at $150 \mathrm{x} g$ and the supernatant was injected directly onto the HPLC column. Retention time for the As species was determined using a species mix comprising standards of $50 \mu \mathrm{g} \mathrm{L}^{-1}$ arsenate, arsenite, DMA and MMA.

Element specific detection of arsenic was achieved using an ICP-MS 7500c (Agilent Technologies). The outlet of the HPLC was connected, via Teflon tubing to a T-piece. Internal standard was added post-column using the ICP-MS's peristaltic pump and mixed with the column effluent in the T-piece, which connected directly to the inlet of the ICP-MS neubulizer. The elements measured were As $(\mathrm{m} / \mathrm{z} 75)$ and $\operatorname{In}(\mathrm{m} / \mathrm{z} 115)$. Argon chloride interference effects on $\mathrm{m} / \mathrm{z} 75$ were monitored on $\mathrm{m} / \mathrm{z} 77$ and 82 . Chromatographic peaks were integrated and their concentration determined using a 
five-point calibration of $\operatorname{DMA}^{\mathrm{V}}\left(0,5,10,15\right.$, and $25 \mu \mathrm{g}$ of As $\left.\mathrm{L}^{-1}\right)$. Because arsenite and arsenate can interconvert during extraction (1), only total inorganic arsenic is reported rather than individual inorganic arsenicals. 


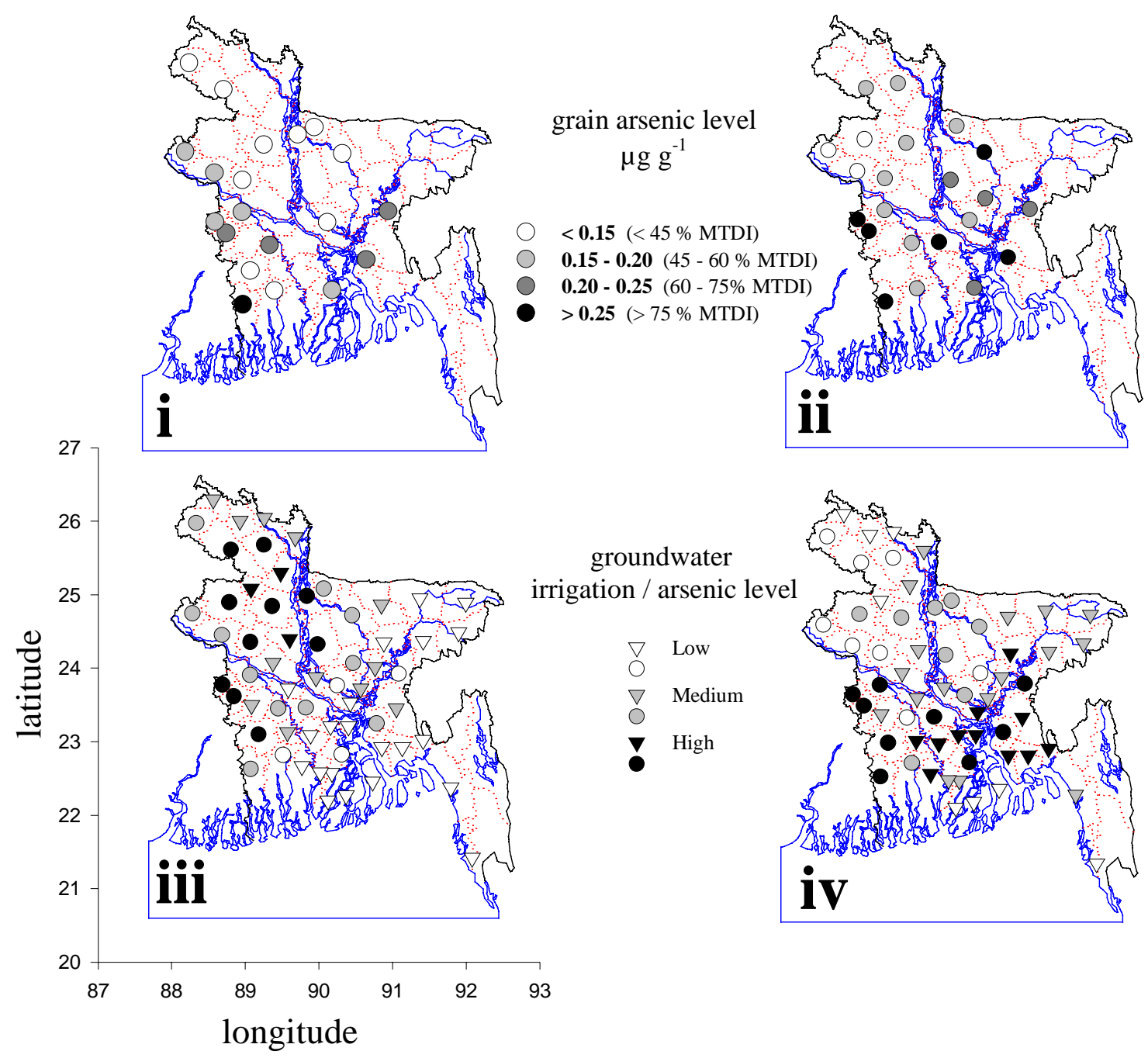

Fig S1. Geographical distribution of (i) arsenic levels in Aman rice (ii) arsenic levels in Boro rice (iii) groundwater irrigation (4) (iv) groundwater arsenic level (using NGS (23) data). Circle symbol indicates districts included in the rice survey. Triangle symbol indicates districts not included in rice survey. Contribution of inorganic arsenic to maximum tolerable daily intake (MTDI) assumes a body weight of $60 \mathrm{~kg}$, a consumption rate of $0.5 \mathrm{~kg}$ per day, a percentage of inorganic arsenic of $80 \%(8)$ and a bioavailability when cooked of $90 \%$ (32). 


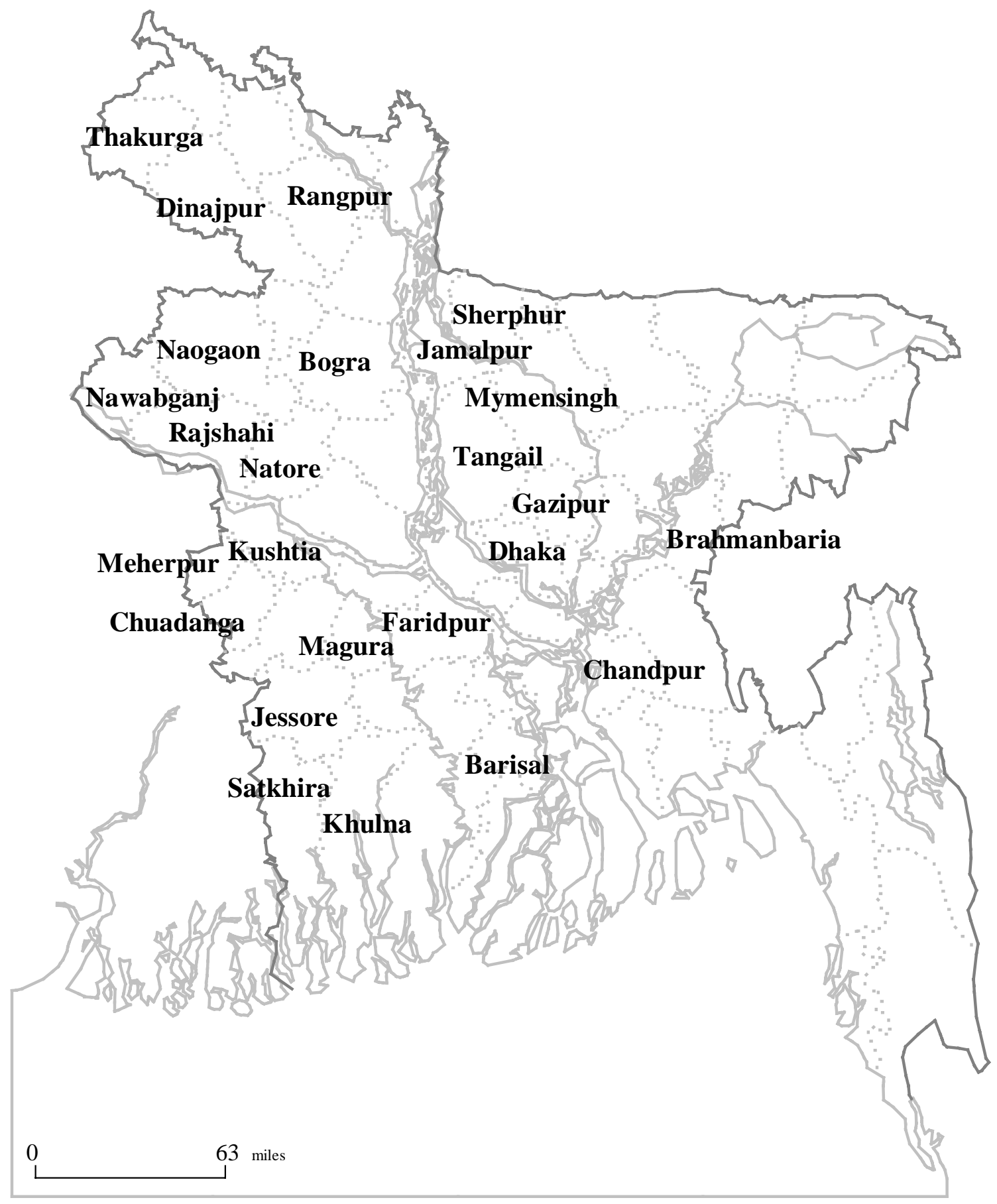

Fig S2. District Map of Bangladesh. Only districts where samples were collected are shown. 


\section{Part B:}

Vegetables. There was wide variation in As levels between and within vegetable categories (Table S1.). The mean As levels of leafy vegetables ranged from $0.13 \mu \mathrm{g} \mathrm{g}$ ${ }^{1} \mathrm{~d} . w \mathrm{t}$. found in amaranth leaf, to $0.79 \mu \mathrm{g} \mathrm{g}^{-1} \mathrm{~d}$.wt. observed in radish leaf. Similarly, for fruit vegetables mean levels varied from $0.11 \mu \mathrm{g} \mathrm{g}^{-1} \mathrm{~d}$.wt. in drum sticks to 0.62 $\mu \mathrm{g} \mathrm{g}^{-1} \mathrm{~d}$.wt in cucumber. Root and tuber vegetables means ranged from $0.06 \mu \mathrm{g} \mathrm{g}^{-1}$ d.wt. in onion to $0.48 \mu \mathrm{g} \mathrm{g}^{-1}$ d.wt. in giant taro. The mean As levels in leafy vegetables $\left(0.38 \mathrm{~g}^{-1} \mathrm{~d}\right.$.wt.) was higher than in root or tuberous vegetables $\left(0.34 \mu \mathrm{g} \mathrm{g}^{-1}\right.$ d.wt.), and fruit vegetables (0.30 $\mathrm{g}^{-1} \mathrm{~d}$.wt. $)$.

Based on maximum recorded As levels the ten vegetables with the highest As values were arum stolon $\left(1.93 \mu \mathrm{g} \mathrm{g}^{-1}\right.$ d.wt. $)>$ brinjal $\left(1.59 \mu \mathrm{g} \mathrm{g}^{-1}\right.$ d.wt. $)>$ cucumber $(1.17 \mu \mathrm{g}$ $\mathrm{g}^{-1}$ d.wt. $)>$ lady's finger $\left(1.06 \mu \mathrm{g} \mathrm{g}^{-1}\right.$ d.wt. $)>$ coriander $\left(0.98 \mu \mathrm{g} \mathrm{g}^{-1} \mathrm{~d} . \mathrm{wt}\right)>$ potato $\left(0.89 \mu \mathrm{g} \mathrm{g}^{-1}\right.$ d.wt. $)>$ long yard bean $\left(0.87 \mu \mathrm{g} \mathrm{g}^{-1}\right.$ d.wt. $)>$ radish leaf $\left(0.79 \mu \mathrm{g} \mathrm{g}^{-1}\right.$ d.wt. $)$ $>$ giant taro $\left(0.69 \mu \mathrm{g} \mathrm{g}^{-1} \mathrm{~d}\right.$.wt. $)>$ vegetable papaya $\left(0.69 \mu \mathrm{g} \mathrm{g}^{-1} \mathrm{~d}\right.$.wt. $)$. The mean maximum recorded As level for root and tuberous vegetables $\left(0.74 \mu \mathrm{g} \mathrm{g}^{-1} \mathrm{~d}\right.$.wt. $)$ was higher than for fruit vegetables $\left(0.56 \mu \mathrm{g} \mathrm{g}^{-1} \mathrm{~d} . w \mathrm{t}\right.$. $)$ and leafy vegetables $\left(0.39 \mu \mathrm{g} \mathrm{g}^{-1}\right.$ d.wt.).

Speciation of As in vegetables. Speciation of As in freeze dried samples was conducted on arum stolon and tuber, potato, bitter gourd, ribbed gourd, pointed gourd, teasel gourd, plantain banana and long yard bean (Table S2.). In all the samples, only the inorganic forms of As were present. The mean As extraction by TFA from different vegetables varied from $79 \%$ of the total As, determined by nitric acid digestion, in Arum stolon to $128 \%$ in potato (Table S2.). The overall average 
extraction efficiency for root and tuberous vegetables was $102 \%$, whilst for fruit vegetables it was $89 \%$. Mean quantitative chromatographic recoveries from the sum of the $\mathrm{As}^{\mathrm{III}}$ and $\mathrm{As}^{\mathrm{V}}$ species in the TFA extracts varied from 90 to $108 \%$, determined by TFA extraction. Further use of TFA as an efficient extractant of As species in vegetables is supported by our work.

Pulses \& Spices. The concentrations of As in pulses were lower compared to those found in vegetable samples (Table S1.). The average As levels in pulses did not exceed $0.10 \mu \mathrm{g} \mathrm{As}^{-1} \mathrm{~d}$.wt. The maximum concentration of As was recorded in

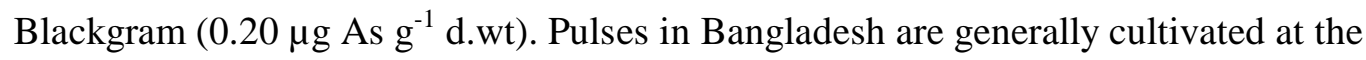
end of the wet season using the residual moisture after flood. Farmers rarely irrigate their fields for pulse cultivation. Generally, pulses have lower concentration of As compared to irrigated rice and vegetables.

Total As concentrations in different types of spices varied widely ranging between $0.04 \mu \mathrm{g} \mathrm{g}^{-1}$ in garlic to $0.49 \mu \mathrm{g} \mathrm{g}^{-1}$ in coriander (Table S1.). Based on the mean As concentration $\left(\mu \mathrm{g} \mathrm{g}^{-1}\right)$, the spices followed the order: coriander $(0.49)>$ chilli $(0.24)>$ turmeric $(0.15)>$ ginger $(0.09)>$ garlic (0.04). Information on As concentration in spices is limited.

Speciation of As in pulses \& spices. In our study there were no organic forms of As in any of the pulses or spices (Table S2.). The average extraction efficiency from pulses was only $45 \%$. It appears that a significant proportion of As is non-extractable using TFA. Mean quantitative chromatographic recoveries suggest that the pulse extract is elutable using these applied HPLC methods. The As levels in the extracts 
were only marginally higher that the limits of detection so definitive conclusions can not be drawn. The extraction efficiency for spices was better, with an overall average of $70 \%$. Recoveries varied from $61 \%$ in turmeric to $80 \%$ in ginger. As speciation for the NIST 1568a rice flour certified reference material is shown in Table S3.

\section{Part C:}

Dietary Exposure. In Bangladesh, vegetables make up approximately $16 \%$ of the total diet. If inorganic As dietary exposure is predicted assuming the average consumption rate of fresh vegetables to be $130 \mathrm{~g} \mathrm{~d}^{-1}$, for a $60 \mathrm{~kg}$ adult, based on this surveys maximum recorded As levels, then the three main leafy vegetable contributors to the MTDI are radish leaf (6\%) spinach (5\%) and cabbage (2\%) (Table S1.). For fruit vegetables, vegetable banana (20\%) was the highest followed by Lady's Finger (16 $\%)$ and Brinjal (14\%). Potato (25\%) was the largest contributor of the root and tuberous vegetables and of all the vegetables surveyed, followed by arum stolon (21 $\%)$ and giant taro (20\%) (Table S1.).

On an average, a Bangladeshi adult of body weight of $60 \mathrm{~kg}$ consumes $12 \mathrm{~g}$ of pulses daily. The amount of As ingestion would be from 0.32 to $1.03 \mu \mathrm{g} \mathrm{day}^{-1}$ which is about $0.3-0.8 \%$ of the MTDI for an adult of $60 \mathrm{~kg}$ body weight (Table S1). A Bangladeshi adult with a body weight of $60 \mathrm{~kg}$ consumes about $5 \mathrm{~g}$ of spices daily. The amount of As ingested would be between 0.2 to $0.5 \mu \mathrm{g} \mathrm{day}^{-1}$, which is about $0.2-0.4 \%$ of the MTDI for an adult of $60 \mathrm{~kg}$ body weight (Table S1). When contribution towards MTDI from vegetables, pulses and spices is considered alongside rice, vegetables are 
only a minor contributor to MTDI. So, even thought higher levels of As have been

found in some vegetables than rice, because much more rice is consumed, it is a much more important source of As exposure. 


\begin{tabular}{|c|c|c|c|c|c|c|c|c|c|c|}
\hline & \multirow[t]{2}{*}{ English } & \multirow[t]{2}{*}{ Bengali } & \multirow[t]{2}{*}{ Latin } & \multirow[t]{2}{*}{ Family } & \multirow[t]{2}{*}{$\mathbf{n}$} & \multicolumn{3}{|c|}{$\begin{array}{r}\text { Arsenic level } \\
\mu \mathrm{g} \mathrm{As} \mathrm{g}^{-1}\end{array}$} & \multirow{2}{*}{$\begin{array}{c}\text { Dry } \\
\text { matter } \\
-\quad \%\end{array}$} & \multirow{2}{*}{$\begin{array}{c}\text { Contribution } \\
\text { to MTDI } \\
\%\end{array}$} \\
\hline & & & & & & Mean & $\min$ & $\max$ & & \\
\hline \multirow{5}{*}{$\begin{array}{l}\text { Leafy } \\
\text { Vegetable }\end{array}$} & Indian spinach & Pui shak & Basella alba & Basellaceae & 3 & $0.14 \pm 0$ & 0.13 & -0.14 & 9 & 1.3 \\
\hline & Amaranth & Data shak & Amaranthus lividus & Amanarthaceae & 3 & $0.13 \pm 0$ & 0.10 & -0.16 & 13 & 2.1 \\
\hline & Cabbage & Badha kopi & Brassica campestris & Cruciferae & 1 & 0.24 & 0.24 & -0.24 & 9 & 2.2 \\
\hline & Spinach & Palang shak & Spinacia oleraceae & Chenopodiaceae & 1 & 0.62 & 0.62 & -0.62 & 8 & 5.1 \\
\hline & Radish leaf & Mula shak & Raphanus sativus & Cruciferae & 1 & 0.79 & 0.70 & -0.79 & 7 & 5.7 \\
\hline \multirow{16}{*}{$\begin{array}{l}\text { Fruit } \\
\text { Vegetable }\end{array}$} & Pumpkin & Mishti Kumra & Cucurbita moschata & Cucurbitaceae & 3 & $0.12 \pm 0$ & 0.11 & -0.12 & 16 & 2.0 \\
\hline & Cow pea & Barbati & Vigna unguiculata & Fabaceae & 1 & 0.15 & 0.15 & -0.15 & 15 & 2.3 \\
\hline & Ribbed gourd & Jhinga & Luffa acutangula & Cucurbitaceae & 4 & $0.13 \pm 0.1$ & 0.07 & -0.17 & 6 & 1.1 \\
\hline & Drum stick & Shajna & Moringa oleifera & Moringaceae & 4 & $0.11 \pm 0.1$ & 0.08 & -0.19 & 15 & 2.9 \\
\hline & Pointed gourd & Patal & Trichosanthes dioica & Cucurbitaceae & 7 & $0.16 \pm 0.1$ & 0.10 & -0.23 & 11 & 2.6 \\
\hline & Bitter gourd & Karola & Momordica charantia & Cucurbitaceae & 4 & $0.16 \pm 0.1$ & 0.07 & -0.29 & 10 & 3.0 \\
\hline & White gourd & Chal kumra & Benincasa hispida & Cucurbitaceae & 3 & $0.22 \pm 0.1$ & 0.15 & -0.31 & 5 & 1.6 \\
\hline & Bottle gourd & Lau & Lagenaria vulgaris & Cucurbitaceae & 3 & $0.42 \pm 0.1$ & 0.32 & -0.47 & 7 & 3.4 \\
\hline & Teasle gourd & Kakrole & Momordica dioica & Cucurbitaceae & 4 & $0.41 \pm 0.1$ & 0.38 & -0.48 & 11 & 5.4 \\
\hline & Plantain banana & Kanch kola & Musa cavendishi & Musaceae & 5 & $0.22 \pm 0.2$ & 0.05 & -0.50 & 36 & 18.6 \\
\hline & Sanke gourd & Chichinga & Trichosanthes anguina & Cucurbitaceae & 4 & $0.31 \pm 0.2$ & 0.13 & -0.59 & 5 & 3.0 \\
\hline & Vegetable papaya & Papay & Carica papaya & Caricaceae & 4 & $0.40 \pm 0.2$ & 0.11 & -0.69 & 8 & 5.7 \\
\hline & Long yard bean & Borboti & Vigna unguiculata & Leguminosae & 3 & $0.55 \pm 0.3$ & 0.33 & -0.87 & 14 & 12.6 \\
\hline & Lady's finger & Dheros & Abelmoschus esculentus & Malvacea & 6 & $0.34 \pm 0.4$ & 0.08 & -1.06 & 14 & 15.3 \\
\hline & Cucumber & Shosha & Cucumis sativa & Cucurbitaceae & 4 & $0.62 \pm 0.4$ & 0.14 & -1.17 & 5 & 6.0 \\
\hline & Brinjal & Begun & Solanum melongena & Solanaceae & 5 & $0.50 \pm 0.6$ & 0.14 & -1.59 & 8 & 13.1 \\
\hline \multirow{6}{*}{$\begin{array}{l}\text { Root } \\
\& \\
\text { Tuber } \\
\text { Vegetable }\end{array}$} & Onion & Peaj & Allium cepa & Alliaceae & 5 & $0.06 \pm 0.1$ & $<0.04$ & -0.15 & 12 & 1.9 \\
\hline & Arum tuber & Kachu & Colocasia esculenta & Araceae & 4 & $0.20 \pm 0.1$ & 0.09 & -0.31 & 26 & 8.3 \\
\hline & Elephant foot & $\mathrm{Ol}$ & Amorphophallus campanulatus & Araceae & 3 & $0.20 \pm 0.2$ & 0.06 & -0.47 & 24 & 11.6 \\
\hline & Giant taro & Mankachu & Alocasia indica & Araceae & 3 & $0.48 \pm 0.3$ & 0.09 & -0.69 & 27 & 19.2 \\
\hline & Potato & Alu & Solanum tuberosum & Solanaceae & 3 & $0.38 \pm 0.5$ & 0.05 & -0.89 & 26 & 23.9 \\
\hline & Arum stolon & Kachu lati & Colocasia esculenta & Araceae & 3 & $0.74 \pm 1$ & 0.05 & -1.93 & 10 & 19.9 \\
\hline \multirow[t]{5}{*}{ Pulses } & Mung bean & Mung kalai & Vigna radiate & Leguminosae & 5 & $0.03 \pm 0$ & $<0.04$ & -0.07 & 88 & 0.6 \\
\hline & Lentil & Masuri & Lens culinaris & Leguminosae & 5 & $0.04 \pm 0$ & $<0.04$ & -0.09 & 91 & 0.8 \\
\hline & Chickpea & Chhola & Cicer arietinum & Leguminosae & 5 & $0.05 \pm 0$ & $<0.04$ & -0.09 & 86 & 0.7 \\
\hline & Khesari- & khesari & Lathyrus sativus & Leguminosae & 5 & $0.06 \pm 0.1$ & $<0.04$ & -0.14 & 87 & 1.2 \\
\hline & Blackgram & Mashkalai & Vigna mungo & Leguminosae & 5 & $0.10 \pm 0.1$ & $<0.04$ & -0.20 & 86 & 1.6 \\
\hline \multirow[t]{5}{*}{ Spices } & Garlic & Rasun & Allium sativum & Alliaceae & 5 & $0.04 \pm 0$ & $<0.04$ & -0.05 & 100 & 0.2 \\
\hline & Ginger & Ada & Zinger officinale & Zingiberaceae & 5 & $0.09 \pm 0.1$ & 0.04 & -0.15 & 100 & 0.6 \\
\hline & Turmeric & Halud & Curcuma longa & Zingiberaceae & 5 & $0.15 \pm 0.1$ & 0.08 & -0.31 & 100 & 1.2 \\
\hline & Chilli & Marich & Capsicum frutescens & Solanaceae & 3 & $0.24 \pm 0.2$ & 0.11 & -0.43 & 100 & 1.7 \\
\hline & Coriander & Dhonea & Corindrum sativum & Umbelliferae & 7 & $0.49 \pm 0.4$ & 0.10 & -0.98 & 100 & 3.9 \\
\hline
\end{tabular}

Table S1. Range and average of As concentrations expressed on a dry weight basis for vegetables, pulses and spices. Mean dry weights $( \pm$ s.e) and ranges are given. Modelled human arsenic ingestion $\left(\mu \mathrm{g} \mathrm{d}^{-1}\right)$ based on maximum recorded As levels, assumes a consumption of $130 \mathrm{~g}$ fresh vegetable day ${ }^{-1,} 12 \mathrm{~g}$ pulses and $5 \mathrm{~g}$ dry spices day ${ }^{-1}$ by an adult of $60 \mathrm{~kg}$ body weight. 


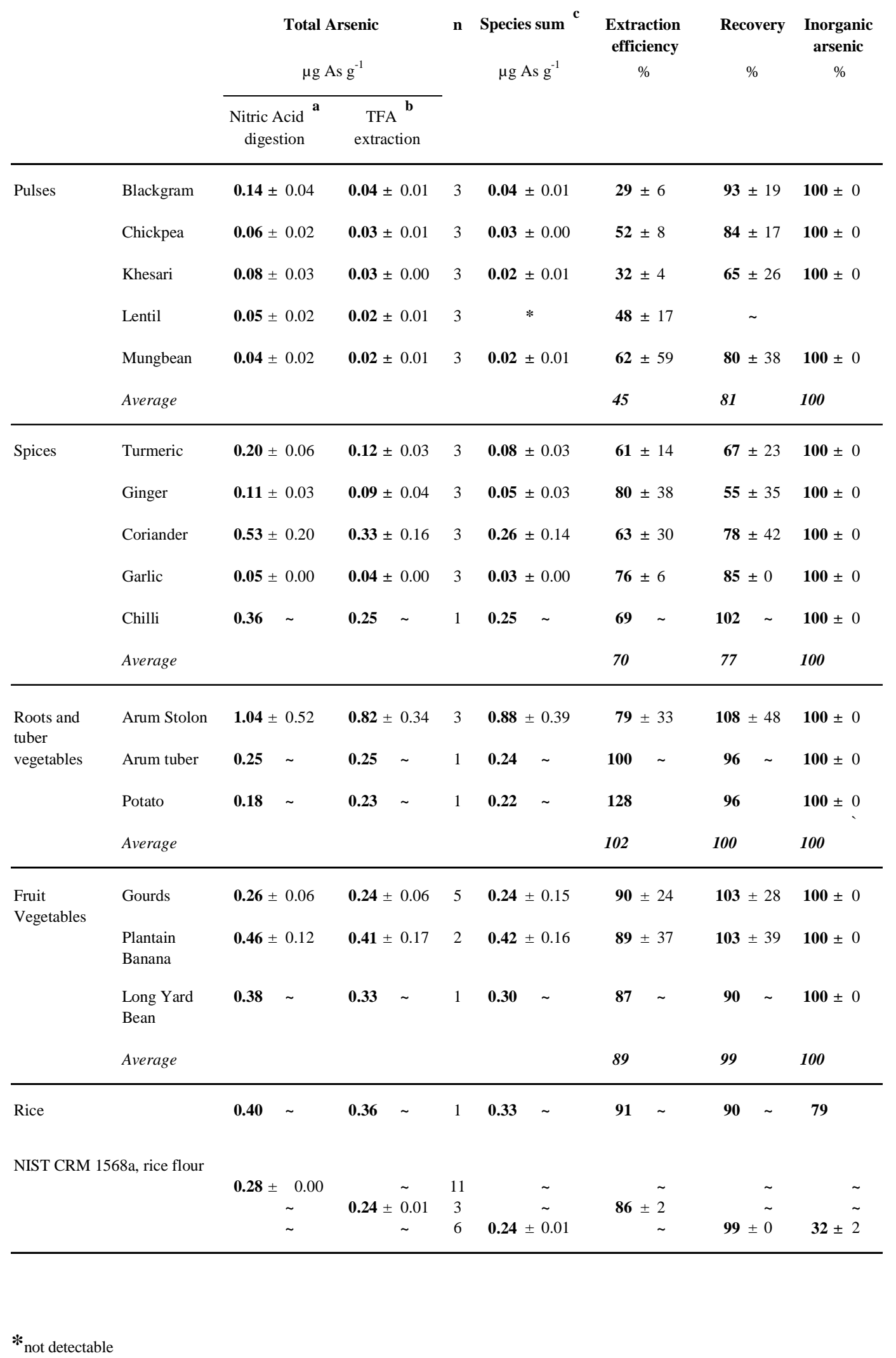

Table S2. Arsenic speciation of Bangladesh vegetables, pulses and spices. Extraction efficiency $=([\mathrm{b}] /[\mathrm{a}]) \times 100$. Recovery $=([\mathrm{c}] /[\mathrm{b}]) \times 100$. 


\begin{tabular}{ccccccccc}
$\begin{array}{c}\text { total } \\
\text { arsenic }\end{array}$ & $\mathrm{n}$ & $\mathbf{D M A}^{\mathbf{v}}$ & $\mathbf{M A}^{\mathbf{v}}$ & $\begin{array}{c}\text { total inorganic } \\
\text { arsenic }\end{array}$ & $\begin{array}{c}\text { species } \\
\text { sum }\end{array}$ & $\begin{array}{c}\text { extraction } \\
\text { efficiency }\end{array}$ & $\begin{array}{c}\text { organic } \\
\text { arsenic }\end{array}$ & $\begin{array}{c}\text { inorganic } \\
\text { arsenic }\end{array}$ \\
$\mu \mathrm{g} \mathrm{As} \mathrm{g}^{-1}$ & & $\mu \mathrm{g} \mathrm{As} \mathrm{g}^{-1}$ & $\mu \mathrm{g} \mathrm{As} \mathrm{g}^{-1}$ & $\mu \mathrm{g} \mathrm{As} \mathrm{g}^{-1}$ & $\mu \mathrm{g} \mathrm{As} \mathrm{g}^{-1}$ & $\%$ & $\%$ & $\%$ \\
\hline $\mathbf{0 . 2 9}$ & 6 & $\mathbf{0 . 1 3 2} \pm 0.01$ & $\mathbf{0 . 0 1 5 5} \pm 0.00$ & $\mathbf{0 . 0 9 7} \pm 0.01$ & $\mathbf{0 . 2 4 5} \pm 0.01$ & $\mathbf{8 4} \pm 3$ & $\mathbf{5 1} \pm 3$ & $\mathbf{3 3} \pm 2$ \\
\hline
\end{tabular}

Table S3. Speciation Analysis of Rice Flour Reference Material NIST CRM 1568a, extracted using 2M TFA. 


$\begin{array}{cccc}\begin{array}{c}\text { Degrees } \\ \text { freedom }\end{array} & \begin{array}{c}\text { Adjusted } \\ \text { mean square }\end{array} & F & \mathrm{P}\end{array}$

\begin{tabular}{|c|c|c|c|c|}
\hline Rice Season & 1 & 292972 & 45.93 & $<0.001$ \\
\hline \multicolumn{5}{|l|}{ Groundwater } \\
\hline Arsenic & 1 & 463950 & 72.73 & $<0.001$ \\
\hline \multicolumn{5}{|l|}{ Rice Season } \\
\hline X & 1 & 66 & 0.01 & 0.919 \\
\hline $\begin{array}{c}\text { Groundwater } \\
\text { Arsenic }\end{array}$ & & & & \\
\hline
\end{tabular}

Table S4. Analysis of variance of the As grain level of rice grown in either the Aman or Boro season, from districts with mean As groundwater levels above or below $50 \mu \mathrm{g}$ As $\mathbf{L}^{-1}$. The data was ranked prior to analysis. 


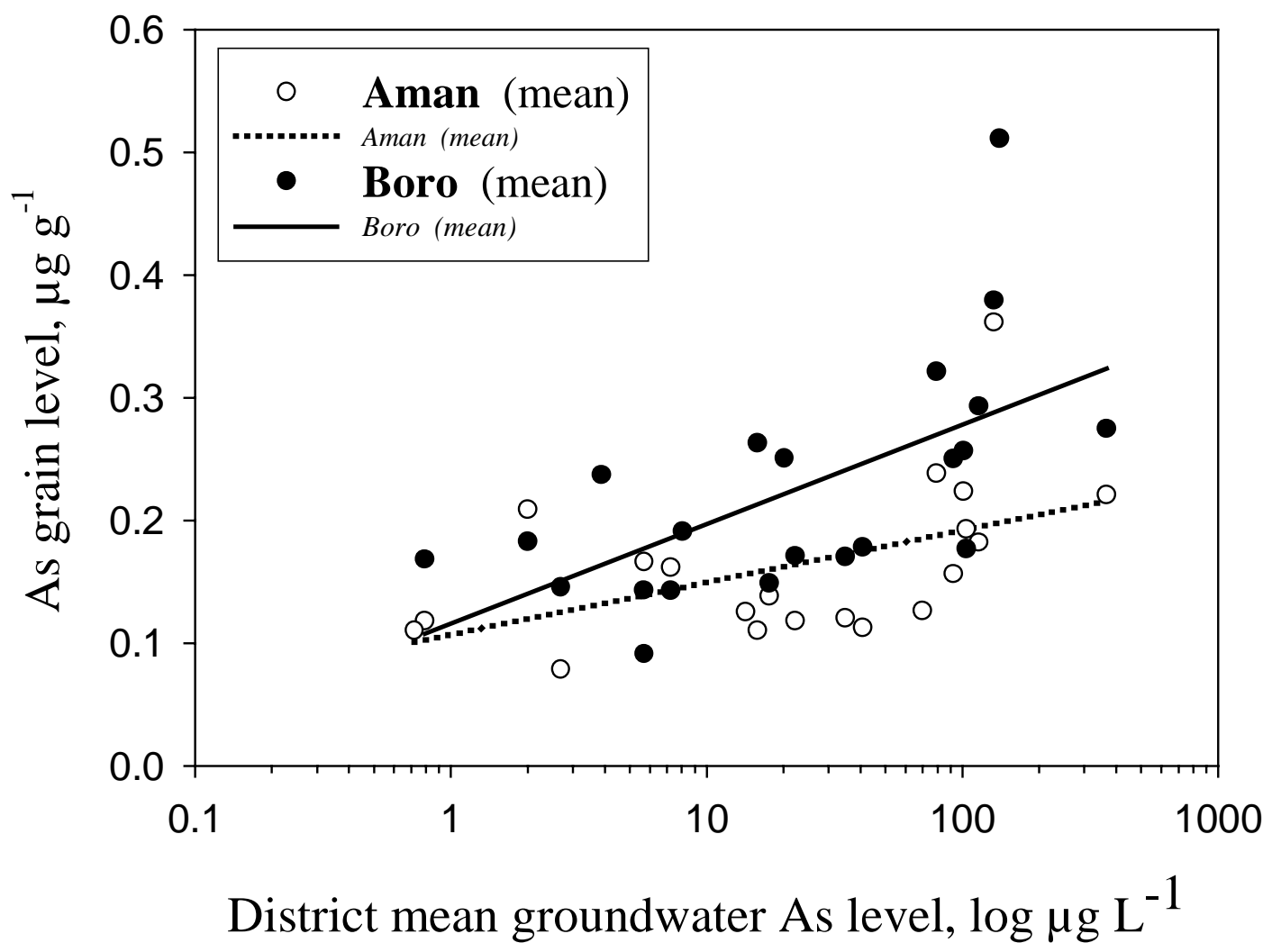

Fig S3. Regression of district mean rice grain level against mean log groundwater As. 


\begin{tabular}{|c|c|c|c|c|c|}
\hline & $\mathbf{R}^{2}$ & Coef & ients & Analysi & riance \\
\hline & & $y^{0}$ & $\mathrm{a}$ & $\mathrm{F}$ & $\mathrm{P}$ \\
\hline Aman & 0.26 & 0.11 & 0.042 & 6.25 & 0.022 \\
\hline Boro & 0.38 & 0.12 & 0.081 & 12.10 & 0.002 \\
\hline
\end{tabular}

Table S5. Results of the regression of district mean groundwater As level against mean district As rice grain levels, for Aman \& Boro season rice. 


\section{References:}

(1) Abedin, M.J.; Cresser, M.S.; Meharg, A.A.; Feldmann, J.; Cotter-Howells, $\mathrm{J}$. Arsenic accumulation and metabolism in rice (Oryza sativa L.), Environ. Sci. Technol. 2002, 36, 962-968.

(2) Heitkemper, D.T.; Vela, N.P.; Stewart, K.R.; Westphal, C.S. Determination of total and speciated arsenic in rice by ion chromatography and inductively coupled plasma mass spectrometry, J. Anal. Atom. Spectrom. 2001, 16, 299-306. 